\begin{tabular}{|c|c|}
\hline 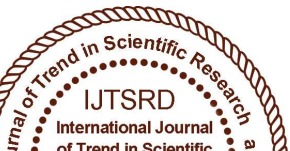 & $\begin{array}{l}\text { International Journal of Trend in Scientific } \\
\text { Research and Development (IJTSRD) }\end{array}$ \\
\hline $\begin{array}{lll} & \\
0\end{array}$ & International Open Access Journal \\
\hline 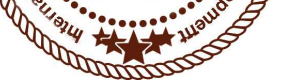 & ISSN No: $2456-6470 \mid$ www.ijtsrd.com | Volume - 2 | Issue -5 \\
\hline
\end{tabular}

\title{
A Study on the General Information and Food Frequency of Self Help group Women of North Madras at Khadi Kraft and Village Industry Board, Kuralagam
}

K. Tryphaena Priyadharshini, D. Annette Beatrice*

*Associate Professor

Department of Home Science, Women's Christian College, Chennai, India

\section{ABSTRACT}

A Self-Help Group (SHG) is a voluntary association of men or women in similar economic conditions. The aim of the study is to the general information of women self-help group and to assess the dietary consumption pattern using a food frequency questionnaire. The general information of the subjects includes age, educational qualification, monthly family income, religion, marital status, family type, family size and disease condition. This study is the experimental design study. For this study, 153 women were chosen from Khadi Kraft and Village industry board, Kuralagam, aged 25 to 65 years. The results showed that most $(38.6 \%)$ of the subjects fall in the middle age group. Fifty per cent of the subject's income level is in between Rs. 5000 to Rs. 10,000 . Subjects have their educational qualification up to secondary school level $(30 \%)$ and there are also subjects who had obtained their degree $(26 \%)$.

The frequency of food consumption was examined based on the major food groups which includes the cereals, pulses and legumes, milk and milk products, meat and meat products, vegetables and fruits, fats and oils, and sugar products. Rice (98\%), milk (93.5 $\%)$, sunflower oil (77\%) and sugar (91.5\%) are included in their diet daily whereas others foods were included in weekly or monthly basis. This study helped to under the economic status and the dietary pattern of the self-help group women.

Keywords: Consumption; Food frequency;Self-help group; Subjects

\section{INTRODUCTION}

Self-Help Group is a development group for the poor and marginalized. The purpose of the Self-Help Group is to build the functional capacity of the poor and to marginalize in the field of employment and income generating activities. People are responsible for their own future by organizing themselves into SHG's [1]. Self - Help Groups are popular and famous in India and South-East Asian countries. In Bangladesh, Muhammad Yunus developed this concept for the poorest of the poor. It is an association of the poor people specially women who belong to the same social \& economic background. The SHGs are usually informal groups of a locality or area, whose members have a common need and importance towards collective action. These groups normally consist of 10 to 20 members. Members of the group meet regularly, make their share of contribution [2].

Women are a vital part of the Indian Economy, both at the national and the household levels. They make one-third of the national labour force. Compared with their men folk, Indian women contribute a much larger share of their earnings to basic family maintenance with the result that women's earnings positively and immediately affect the incidence and the security of poverty. SHGs function on the basis of co-operative principles and provide a forum for members to extent support to each other. It is considered as a means of empowerment [3].

Women are more likely to suffer from nutritional deficiencies than men are, for reasons including women's reproductive biology, low social status, 
poverty, and lack of education. Sociocultural traditions and disparities in household work patterns can also increase women's chances of being malnourished [4].

Women are experiencing increase in the prevalence of chronic diseases [5].

The risk of developing diabetes, gallstones, hypertension, heart disease, and stroke increased with severity of overweight among both women and men. Women who were overweight but not obese (i.e., BMI between 25.0 and 29.9) were also significantly more likely than their leaner peers to develop gallstones, hypertension, high cholesterol level and heart disease [6].

The major causes of poor nutritional status in women differ from those in men throughout much of adult life, with malignant neoplasms ranking highest among adult women aged 45-64 years and CVD ranking highest for men in the same age range. After the age of 64 years, however, heart disease is the leading cause of death in both men and women [7].

The relative risk for fatal coronary heart disease associated with diabetes is $50 \%$ higher in women than it is in men. Type 2 diabetes has long been known as a risk factor for coronary heart disease and is conservatively estimated to increase the risk of a fatal event by two fold. The association between diabetesand coronary heart disease has been suggested to be stronger in women than in men [8].

\section{MATERIALS AND METHODS}

The aim of the study was to collect the general information on economic status and to obtain information on the frequency of food consumption.

The study population comprised of 153 self-help group of women from the Tamil Nadu Khadi Kraft and Village Industries Board, Kuralagam who are aged 25 to 65 years and above.

The data was collected from each woman. It comprised of the age, educational qualification, marital status, family type, family size, income level, religion and diseases condition.

Dietary intake was assessed using the food frequency questionnaire to know the consumption of various foods and their frequency. The questionnaire covered all the food groups. The frequency of consumption was recorded in terms of daily, weekly, monthly and never.

\section{A. Analysis of Data}

Data obtained through questionnaire were coded, classified and tabulated for further statistical analysis. The data collected were analysed using suitable statistical analysis.

\section{III.RESULTS AND DISCUSSION General Information}

The general information of the subjects included age, educational qualification, monthly family income, religion, marital status, family type, family size and disease condition. The age of the subjects were categorized from 25 to 65 years and above. Almost 39 per cent of the subjects belong to the age group of 45 to 55 years of age. With regard to educational qualification 30 per cent of the subjects were qualified up to secondary school level. Twenty three per cent of the subjects had studied only up to 3rd standard whereas twenty six percent of the subjects had perused their degree. Around $81.7 \%$ of the subjects belong to the Hindu community. While the subjects from Christian $(15.7 \%)$ and Muslim (2.6\%) communities were found to be less. Many (82\%) of the subjects were married. Only $13 \%$ of the subjects were single and $4.6 \%$ are widow.

It is found that most $(68.8 \%)$ of the families belong to the nuclear type. Joint families are found to be only $27 \%$ and extended families are around 4.6\%.Many $(73.2 \%)$ of the subjects families are small sized; only two to four members are present in the family.

\section{A. Income level}

The income levels of the subjects are presented in the figure 1 below.

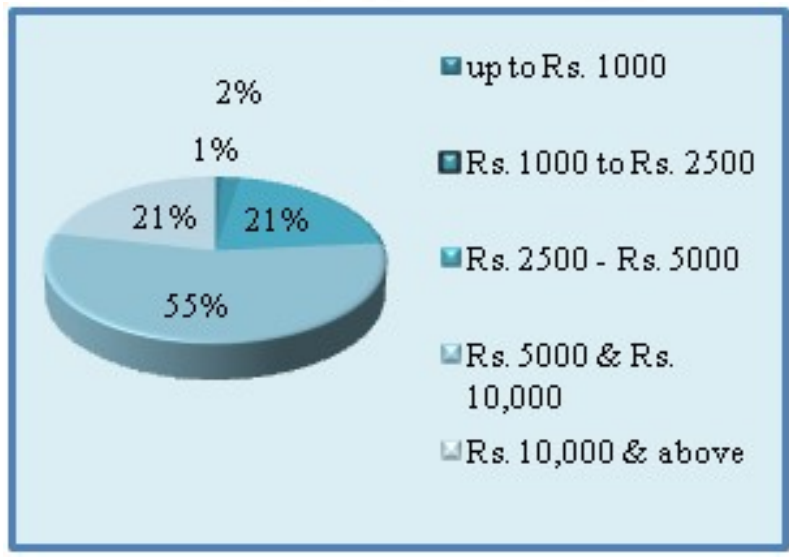

Fig. 1 Percentage Distribution of Subjects According to Family Income (monthly) 
It can be seen that $55 \%$ of the subject's family monthly income was Rs. 5000 to Rs. 10,000. Equal percentage $(21 \%)$ of the subjects earns between Rs. 1000 to Rs. 2500 and Rs. 5000 and Rs. 10,000 .

\section{B. Disease Condition}

The percentage distribution of the subjects according to the disease condition is presented in the graph below (Figure 2)

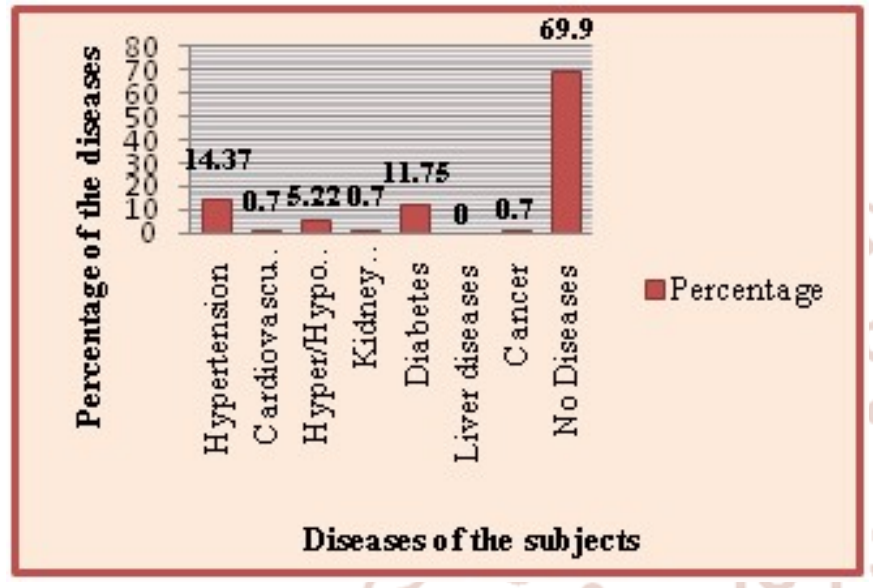

Fig. 2 Percentage Distribution of Subjects According to Disease Condition

Seventy percent of the subjects did not suffer from any disease condition. But there were few subjects with hypertension (14.3\%) and diabetes $(11.75 \%)$.

\section{Frequency of Food Consumption}

The food consumption pattern of the subjects was studied and tabulated according the food groups such ascereals, pulses and legumes, milk and milk products, meat and meat products, vegetables and fruits, fats and oils, and sugar products.

Table1. Percentage Distribution of Subjects According to Frequency of Consumption of Cereals

\begin{tabular}{|l|c|c|c|c|c|c|c|c|}
\hline \multirow{2}{*}{ Cereals } & \multicolumn{2}{|c|}{ Daily } & \multicolumn{2}{c|}{ Weekly } & \multicolumn{2}{c|}{ Monthly } & \multicolumn{2}{c|}{ Never } \\
\cline { 2 - 9 } & No. & $\%$ & No. & $\%$ & No. & $\%$ & No. & $\%$ \\
\hline Rice & 150 & 98 & 3 & 2 & 0 & 0 & 0 & 0 \\
\hline Wheat & 24 & 16 & 105 & 69 & 21 & 14 & 3 & 2 \\
\hline Maida & 7 & 4.6 & 22 & 14 & 92 & 60 & 32 & 21 \\
\hline Ragi & 13 & 8.5 & 20 & 13 & 69 & 45 & 51 & 33 \\
\hline Jowar & 8 & 5.2 & 2 & 1 & 60 & 39 & 83 & 54 \\
\hline Vargu & 10 & 6.5 & 5 & 3 & 36 & 24 & 102 & 67 \\
\hline Bajra & 10 & 6.5 & 5 & 3 & 31 & 20 & 107 & 70 \\
\hline
\end{tabular}

The above table 1 reveals that $98 \%$ of the subjects consume rice on daily basis whereas wheat $(67 \%)$ is consumed on weekly basis. It can be seen that many of the subjects never included millets such as vargu $(66.7 \%)$, bajra (70 \%) and jowar $(54.2 \%)$ in their diet.

Table2. Percentage Distribution of Subjects According to Frequency of Consumption of Pulses and Legumes

\begin{tabular}{|c|c|c|c|c|c|c|c|c|}
\hline \multirow{2}{*}{$\begin{array}{c}\text { Pulses } \\
\text { and } \\
\text { Legumes }\end{array}$} & \multicolumn{2}{|c|}{ Daily } & \multicolumn{2}{|c|}{ Weekly } & \multicolumn{2}{|c|}{ Monthly } & \multicolumn{2}{|c|}{ Never } \\
\hline & No. & $\%$ & To. & $\%$ & 0. & $\%$ & No. & $\%$ \\
\hline & 25 & 16 & 19 & & 7 & & 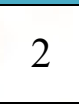 & \\
\hline & 15 & 10 & 99 & 65 & 26 & 17 & 13 & \\
\hline $\operatorname{Re}$ & 20 & 13 & 5 & & 10 & & & J \\
\hline & 70 & 46 & 72 & & & & 3 & 2 \\
\hline $\begin{array}{l}\text { Soya } \\
\text { products }\end{array}$ & 2 & & 16 & & 44 & & 91 & 60 \\
\hline
\end{tabular}

The above table 2 shows that many of the subjects include Bengal gram dhal $(78 \%)$, green gram dhal $(64.7 \%)$, red gram dhal $(75.2 \%)$ and black gram dhal $(47.1 \%)$ on weekly basis in their diet and soya products $(60 \%)$ are never included in the diets by the subjects.

Table3. Percentage Distribution of Subjects According to Frequency of Consumption of Milk and Milk Products

\begin{tabular}{|l|c|c|c|c|c|c|c|c|}
\hline \multirow{2}{*}{$\begin{array}{c}\text { Millk } \\
\text { and } \\
\begin{array}{c}\text { Milk } \\
\text { Products }\end{array}\end{array}$} & \multicolumn{2}{|c|}{ Daily } & \multicolumn{3}{|c|}{ Weekly } & \multicolumn{2}{|c|}{ Monthly } & \multicolumn{2}{c|}{ Never } \\
\cline { 2 - 10 } & No. & $\%$ & No. & $\%$ & No. & $\%$ \\
\hline Milk & 143 & 94 & 6 & 4 & 2 & 1 & 2 & 1 \\
\hline Cheese & 0 & 0 & 4 & 3 & 44 & 29 & 105 & 69 \\
\hline Paneer & 0 & 0 & 5 & 3 & 30 & 20 & 118 & 77 \\
\hline Curd & 52 & 34 & 73 & 48 & 19 & 12 & 9 & 6 \\
\hline
\end{tabular}

From the above table 3 , milk was consumed daily by 93.5 per cent of the subjects drink. Curd (48 \%) was consumed on weekly basis. Many of the subjects never included paneer (77\%) and cheese (69\%) in their diet. 
International Journal of Trend in Scientific Research and Development (IJTSRD) ISSN: 2456-6470

Table5. Percentage Distribution of Subjects According to Frequency of Consumption of Vegetables

\begin{tabular}{|l|c|c|c|c|c|c|c|c|}
\hline \multirow{2}{*}{ Vegetables } & \multicolumn{2}{c|}{ Daily } & \multicolumn{2}{c|}{ Weekly } & \multicolumn{2}{c|}{ Monthly } & \multicolumn{2}{c|}{ Never } \\
\cline { 2 - 9 } & No. & $\%$ & No. & $\%$ & No. & $\%$ & No. & $\%$ \\
\hline Roots \& tubers (carrot, potato, beet root) & 38 & 24.8 & 110 & 71.9 & 5 & 3.3 & 0 & 0 \\
\hline $\begin{array}{l}\text { Green leafy vegetables (spinach, drumstick } \\
\text { leaves) }\end{array}$ & 16 & 10.5 & 109 & 71.2 & 26 & 17 & 1 & 0.7 \\
\hline $\begin{array}{l}\text { Other vegetables ( beans, ladies finger, } \\
\text { drumstick, gourd varieties) }\end{array}$ & 69 & 45.1 & 79 & 51.6 & 2 & 1.3 & 3 & 1.9 \\
\hline
\end{tabular}

The table 5 shows that root and tubers $(72 \%)$, green leafy vegetables $(71 \%)$ and other vegetables $(51.6 \%)$ like beans, ladies finger, drumstick, and gourd varieties were consumed on weekly basis by the subjects.

Table6. Percentage Distribution of Subjects According to Frequency of Consumption of Fruits

\begin{tabular}{|l|l|l|l|l|l|l|l|l|}
\hline \multirow{2}{*}{ Fruits } & \multicolumn{2}{|c|}{ Daily } & \multicolumn{2}{c|}{ Weekly } & \multicolumn{2}{c|}{ Monthly } & \multicolumn{2}{c|}{ Never } \\
\cline { 2 - 10 } & No. & $\%$ & No. & $\%$ & No. & $\%$ & No. & $\%$ \\
\hline Seasonal fruits & 20 & 13 & 51 & 33 & 77 & 50 & 5 & 3.3 \\
\hline Tropical fruits & 4 & 3 & 28 & 18.7 & 73 & 48 & 48 & 31 \\
\hline Citrus fruits & 4 & 3 & 55 & 36 & 82 & 54 & 12 & 7.8 \\
\hline Dried fruits & 3 & 2 & 20 & 13.1 & 68 & 44 & 62 & 41 \\
\hline
\end{tabular}

From the table 6 it is found to be that the consumption of seasonal fruits $(50 \%)$, tropical fruits $(48 \%)$, citrus fruits $(54 \%)$ and dried fruits (44\%) were only on the weekly basis.

Table7. Percentage Distribution of Subjects According to Frequency of Consumption of Fats and Oils

\begin{tabular}{|l|l|l|l|l|l|l|l|l|}
\hline \multirow{2}{*}{ Fats and Oilseeds } & \multicolumn{2}{|c|}{ Daily } & \multicolumn{2}{c|}{ Weekly } & \multicolumn{2}{c|}{ Monthly } & \multicolumn{2}{c|}{ Never } \\
\cline { 2 - 10 } & No. & $\%$ & No. & $\%$ & No. & $\%$ & No. & $\%$ \\
\hline Butter & 3 & 2.0 & 8 & 5.2 & 52 & 34 & 90 & 59 \\
\hline Ghee & 10 & 6.5 & 17 & 11 & 54 & 35 & 72 & 47 \\
\hline Dalda & 6 & 3.9 & 8 & 5.2 & 19 & 12 & 120 & 78 \\
\hline Sunflower oil & 117 & 77 & 22 & 14 & 2 & 1 & 12 & 8 \\
\hline Gingely oil & 43 & 28 & 67 & 44 & 19 & 12 & 24 & 16 \\
\hline Corn/rice bran/ groundnut oil & 40 & 26 & 59 & 39 & 22 & 14 & 32 & 21 \\
\hline Coconut oil & 5 & 3.3 & 13 & 8.5 & 17 & 11 & 118 & 77 \\
\hline
\end{tabular}

The above table 7 reveals that the consumption of sunflower oil was found to be on the daily basis by many ( 77 $\%)$ of the subjects. Gingely oil (44\%) and corn/rice bran/groundnut oil (39\%) are included only on weekly in their diet. Butter $(59 \%)$, Ghee $(47 \%)$, dalda $(78 \%)$ and coconut oil $(77 \%)$ were never included by many of the subjects in their diet.

Table8. Percentage Distribution of Subjects According to Frequency of Consumption of Sugar Products

\begin{tabular}{|l|l|l|l|l|l|l|l|l|}
\hline \multirow{2}{*}{ Sugar Products } & \multicolumn{2}{|c|}{ Daily } & \multicolumn{2}{c|}{ Weekly } & \multicolumn{2}{c|}{ Monthly } & \multicolumn{2}{c|}{ Never } \\
\cline { 2 - 10 } & No. & $\%$ & No. & $\%$ & No. & $\%$ & No. & \multicolumn{1}{c|}{$\%$} \\
\hline Sugar & 140 & 91.5 & 8 & 5.2 & 1 & 0.7 & 4 & 2.6 \\
\hline Jaggery & 3 & 2.0 & 23 & 15 & 78 & 51 & 49 & 32 \\
\hline Honey & 1 & 0.7 & 10 & 6.5 & 56 & 36.6 & 86 & 56.2 \\
\hline
\end{tabular}

Table 8 shows that (91.5\%) majority of the subjects consume sugar daily and few do not consume because of health reason. Fifty one percent and $36.6 \%$ of the subjects consume jaggery and honey on a monthly basis. They include them for dessert preparation and for toppings, while $49 \%$ and $86 \%$ of the subjects never consumed jaggery and honey. 


\section{IV.DISCUSSION}

The study shows that the women mostly belong to the lower middle class income level. It is also found that most of the subjects have finished their secondary school and many of the subjects have finished their degree. Nowadays many women are involved in perusing higher education to stand on their own. These women in Self Help group are working hard to become great entrepreneurs. Many of the members in the group fall between the middle age ( $45-55$ years) categories. Younger generation are also taking part in Self-help groups to improve their skills and to support their family. While coming to their frequency of consumption of foods, we can see that the consumption of the major food groups was found only on the weekly or monthly basis except for rice, milk, sunflower oil and sugar which was included daily in their diet. It is important to take fruits and vegetables in their daily routine, which is important to lead a healthy life.

\section{CONCLUSION}

The self-help group is found to be the fast emerging groups especially for women. The general information of the subjects helped us to know the economic status of each woman and also their disease condition. From

the general observation of frequency of food, it can be seen that there is an unhealthy eating pattern among the subjects. Since the vegetables and fruits and even other major food groups are consumed in weekly or monthly basis, the subjects may lack in nutrition. Awareness on healthy eating habits and nutrition should be given to the subjects in improving their lifestyle.

\section{ACKNOWLEDGEMENT}

We thank Dr. Ponnuraja, Senior Scientist, ICMR, Chennai for helping with statistical analysis of the data.

We thank the Centre for Nutrition Counselling Research and Extension Activities, Department of
Home Science, Women's Christian College for supporting the study with the generous grand.

\section{REFERENCES}

1. Marg, S. (2008). A Report on the Success and Failure of SHG's in India -Impediments and Paradigm of success. Voluntary Operation in Community \& Environment. New Delhi.

2. Anand, P. (2013). What are Self Help groups (SHGs) in India? - Objectives \& Features of SHGs. Priyanka Blog Thoughts.

3. Misra, N. (2013). Self-Help Group (SHG) of India: Meaning, Need and Objectives. Your Article Library. http://www.yourarticlelibrary.com/india-2/selfhelp-group/self-help-group-shg-of-india-meaningneed-and-objectives/66718.

4. Galloway, R. (2002). Women's Perceptions of Iron Deficiency and Anaemia Prevention and Control in Eight Developing Countries. Social Science \& Medicine. 55(4):529-44

5. Barfield. (2012). Preventing Chronic Disease in Women of Reproductive Age: Opportunities for Health Promotion and Preventive Services. Preventive Chronic Disease. 9: E34.

6. Field, A. E. (2001). Impact of Overweight on the Risk of Developing Common Chronic Diseases during a 10-Year Period. Archives of internal medicine American Medical Association. 161(13):1581-6.

7. Willett, W. C. (2000). Adherence to the Dietary Guidelines for Americans and risk of major chronic disease in women. The American Journal of Clinical Nutrition. 72(5):1214-1222.

8. Huxley, R. (2006). Excess risk of fatal coronary heart disease associated with diabetes in men and women: meta-analysis of 37 prospective cohort studies. British Medical Journal (BMJ) Publishing. 14(332):73-78. 